\title{
CORRELATION BETWEEN TOTAL SUSPENDED PARTICLES AND NATURAL RADIONUCLIDE IN MALAYSIA MARITIME AIR DURING HAZE EVENT IN JUNE-JULY 2009
}

\author{
Asnor Azrin Sabuti' ${ }^{*}$, Che Abd Rahim Mohamed ${ }^{2}$ \\ ${ }^{1}$ Department of Marine Science, Kulliyyah of Science, International Islamic University Malaysia IIUM Kuantan Campus 25200 Kuantan, Pahang, \\ Malaysia \\ ${ }^{2}$ School of Environmental and Natural Resource Sciences Faculty of Science and Technology Universiti Kebangsaan Malaysia, 43600 Bangi, \\ Malaysia \\ *Corresponding author email: asnor@iium.edu.my
}

\section{ARTICLE DETAILS}

\section{Article History:}

Received 12 November 2017 Accepted 12 December 2017 Available online 1 January 2018

\section{Keywords:}

Radionuclide, total suspended particles, aerosol, maritime air, haze

\section{ABSTRACT}

Atmospheric particles in the surface air including aerosol and dust were collected using high volume air sampler (HVAS) for obtaining the activity levels of ${ }^{210} \mathrm{~Pb}$ and ${ }^{210} \mathrm{Po}$ over Malaysian waters during the EPSP'09 Scientific Expedition. The average mass concentration of total suspended particles (TSP) in maritime air was $33 \pm 2 \mu \mathrm{g} / \mathrm{m}^{3}$ (ranged from $13 \pm 1$ to $74 \pm 4 \mu \mathrm{g} / \mathrm{m}^{3}$ ). Based on previous literatures, it has been suspected that the haze episodes were mainly due to forest and peat bog fires as well as vehicle and industrial emissions during dry period, especially during southwest monsoon. Consequently, the activity levels of ${ }^{210} \mathrm{~Pb}$ and ${ }^{210} \mathrm{Po}$ in maritime particles were relatively in proportion with the TSP concentrations. Meanwhile, the temporal variation of ${ }^{210} \mathrm{Po} /{ }^{210} \mathrm{~Pb}$ activity ratios in the aerosol samples perhaps related to the difference of residence time airborne particles and contribution from different sources of radionuclides in which ${ }^{210} \mathrm{~Pb}$ and ${ }^{210} \mathrm{Po}$ are not in secular equilibrium. The highest TSP concentrations and ${ }^{210} \mathrm{~Pb}$ and ${ }^{210} \mathrm{Po}$ activities were closely related to warm and dry period during southwest monsoon.

\section{INTRODUCTION}

During the EPSP'09 Scientific Expedition, data on air quality were collected using total suspended particles (TSP) measurements. This parameter is a collective term used for very small solid and/or liquid particles found in the atmosphere [1]. TSP was the first indicator used to represent suspended particles in the ambient air. Alias et al. [1] summarized that the particulate concentrations are depending on the wind or other influencing factors at that particular time such as temperature and humidity. Wind speed and directions will determine the amount of particulate matter at one particular point, since this particulate matters were transported by wind into various direction and distance from the source. The amount of rain fall also contributes to the concentration of air particulates in the air, where it's going to be lower during rainy days. Malaysia is well known for its heavy rainfall. The rain can reduce the amount of air particulates in the air because most of it will be carried away by rain water.

The suspended particles come at respirable size which can presents risks to human health. Because of the large number of sources, particulate matter may contain hundreds of different chemical elements. Fine particles may contain substantial quantities of sulfate, ammonium, nitrate, elemental carbon and condensed organic compounds. Carcinogenic compounds and heavy metals such as arsenic, selenium, cadmium and zinc are also concentrated in these particles. Larger particles, such as soil particles, fly ash, road aggregate, wood ash, soot and pollen are composed primarily of minerals, including silicon, aluminum, potassium, iron, calcium and other alkaline elements [2-4]. These airborne particles may also contain toxic substances such as polycyclic aromatic hydrocarbons (PAHs), semi-volatile and volatile organic compounds (VOCs), organic acids, free radicals, ozone, aldehydes, inorganic materials as well as radionuclides [5-11].

Natural radionuclides being assessed in this study are ${ }^{210} \mathrm{~Pb}$ and ${ }^{210} \mathrm{Po}$, which are daughters of radon gas $\left({ }^{222} \mathrm{Rn}\right)$, emanates from the soil [12]. These radionuclides are members of the decay series from naturally occurring ${ }^{238} \mathrm{U}$ with radioactive half-lives ( $\left.t_{1 / 2}\right)$ of 22.3 years, 138.4 days and
3.82 days, respectively. ${ }^{210} \mathrm{~Pb}$ and its progeny ${ }^{210} \mathrm{Po}$ in the lower layer of the atmosphere are attached to the aerosol and can be transported over long distance $[13,14]$. The ${ }^{210} \mathrm{~Pb}$ and its decay products in atmosphere are being utilized to determine the apparent tropospheric residence times and evaluate the aerosol sources by looking at the ${ }^{210} \mathrm{Po} /{ }^{210} \mathrm{~Pb}$ and ${ }^{210} \mathrm{Bi} /{ }^{210} \mathrm{~Pb}$ ratios [15-17].

Besides natural phenomenon, these radionuclides are also released from industrial processes such as the sintering of ores in steelworks, the burning of coal in coal-fired power stations, the production and use of agricultural fertilisers and forest among others. Polonium and lead can be concentrated through uptake in flora and fauna, and hence can enter the food chain [18-25].

The aim of this study is to measure the concentration of TSP and activity levels of ${ }^{210} \mathrm{Po}$ and ${ }^{210} \mathrm{~Pb}$ in the maritime air along Strait of Malacca, southern South China Sea and Sulu-Sulawesi Seas during EPSP'09 scientific expedition. Thus, the correlation between ${ }^{210} \mathrm{Po}$ and ${ }^{210} \mathrm{~Pb}$ activities with TSP was analyzed to study their relationship and variations during the expedition.

\section{METHODOLOGY}

\subsection{Study area}

Malaysia is surrounded by Strait of Malacca, South China Sea, Sulu Sea and Sulawesi Sea. Strait of Malacca is located in between west of Peninsular Malaysia and Sumatera Indonesia. It is one of an important trade channel in the world. South China Sea is a coastal region which separated Peninsular Malaysia from Sabah and Sarawak (Borneo Island). Sulu Sea and Sulawesi Sea are located at the east of Sabah coastal region. The Ekspedisi Pelayaran Saintifik Perdana 2009 (EPSP'09) was conducted for one and half month from $12^{\text {th }}$ June until $1^{\text {st }}$ August 2009. The journey was covering major part of Malaysian waters including the Strait of Malacca, southern South China Sea (Sabah and Sarawak area), Sulu Sea and Sulawesi Sea (Figure 1). 


\subsection{Sample Collection}

During EPSP the air particulate matter samples were collected by using high volume air sampler. The air sampler was placed $15 \mathrm{~m}$ from sea surface on the highest deck of the ship at $1631.04 \mathrm{~m}^{3} /$ day flow rate by using Whatman filters (EPM 2000) for every 24 hours. The particulate size collected approximately $0.01-100 \mu \mathrm{m}$.

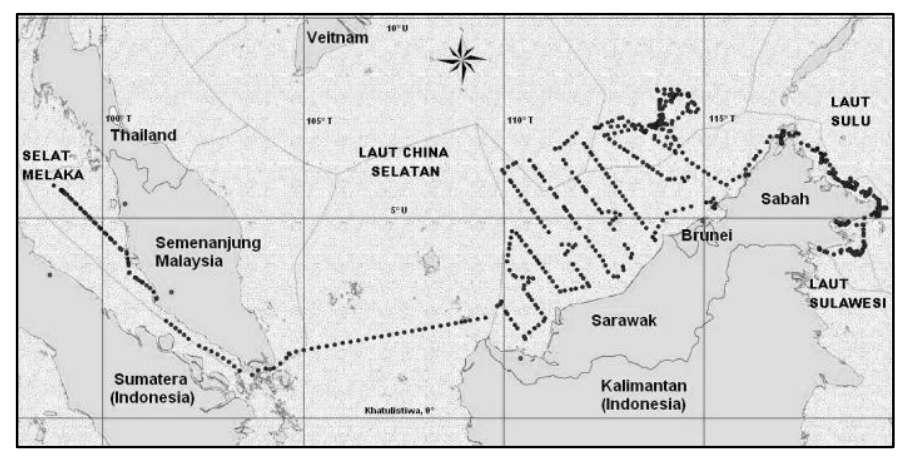

Figure 1: The journey of EPSP'09 Scientific Expedition covers Strait of Malacca, southern South China Sea, Sulu Sea and Sulawesi Sea from $12^{\text {th }}$ June until $1^{\text {st }}$ August 2009.

\subsection{Sequential extraction of ${ }^{210} \mathrm{Po}$ and ${ }^{210} \mathrm{~Pb}$}

The weighed sample was transferred to a Teflon beaker. A known amount of ${ }^{209} \mathrm{Po}$ tracer and $\mathrm{Pb}\left(\mathrm{NO}_{3}\right)_{2}$ carrier was added into the sample for recovery calculation. Approximately 3:2:2:1 ratio of $\mathrm{HNO}_{3}: \mathrm{HCl}: \mathrm{HClO}_{4}: \mathrm{HF}$ was dripped into the sample and heat the sample until it dissolved perfectly at $\pm 70^{\circ} \mathrm{C}$. The sample was dissolved with $0.5 \mathrm{M} \mathrm{HCl}$ after dryness. Ascorbic acid was added until solution become colourless. The sample solution was transferred into beaker for ${ }^{210} \mathrm{Po}$ spontaneously plating onto a silver planchet at $\pm 70{ }^{\circ} \mathrm{C}$ for 3 hours [26]. Finally, the silver planchet was rinsed with de-ionized water and dried. The ${ }^{210} \mathrm{Po}$ was measured with $\alpha$ spectrometer (Canberra model Alpha Analyst Spectroscopy system with a silicon-surface barrier detector).

The final sample solution after spontaneously plating of was ${ }^{210} \mathrm{Po}$ was carried to next step for ${ }^{210} \mathrm{~Pb}$ extraction. Approximately, $5 \mathrm{ml}$ of $\mathrm{HNO}_{3}$ and $1 \mathrm{ml} \mathrm{H}_{2} \mathrm{O}_{2}$ was added into the sample and heat for 15 minutes. After cooled down, $20 \mathrm{mg} / \mathrm{L}$ of $\mathrm{Fe}\left(\mathrm{NO}_{3}\right)_{2}$ carrier was added into the sample followed by $\mathrm{NH}_{3}$ until orange precipitate formed. The sample was centrifuged at 4000 $\mathrm{rpm}$ and the precipitate residue was dissolved with $25 \mathrm{ml} 0.5 \mathrm{M} \mathrm{HNO}_{3}$. The sample solution was electrodeposited on platinum gauze at $2.3 \mathrm{~V}$ for 1 hour. The platinum gauze was rinsed with the mixture of $3 \mathrm{M} \mathrm{HNO}_{3}$ and $30 \% \mathrm{H}_{2} \mathrm{O}_{2}$ before heated and dried. The dried sample was dissolved with $1 \mathrm{M} \mathrm{HNO}_{3}$ and $3 \mathrm{ml} \mathrm{H}_{2} \mathrm{SO}_{4}$. White precipitate $\left(\mathrm{PbSO}_{4}\right)$ formed was filtered and dried. The filter paper was weighed for recovery calculation before wrapped the filter paper on the Perspex disc. The ${ }^{210} \mathrm{~Pb}$ was counted by using gross $\alpha / \beta$ counter (Tennelec model Series 5 XLB low background gas-flowing anti-coincidence alpha-beta counter) 30 days after electrodeposited.

\section{RESULTS AND DISCUSSION}

\subsection{Total Suspended Particles (TSP) concentrations}

During the expedition, data on air quality were collected using total suspended particles (TSP) measurements. From our data in Figure 2, the average mass concentration of TSP in Malaysian maritime air during EPSP'09 Scientific Expedition was $33 \pm 2 \mu \mathrm{g} / \mathrm{m}^{3}$. According to a study, a clear and clean atmospheric conditions in Malaysia usually records a TSP level as low as $0-10 \mu \mathrm{g} / \mathrm{m}^{3}$ and can be as high as $1500 \mu \mathrm{g} / \mathrm{m}^{3}$ in a very dirty environment [1]. The lowest concentration of TSP during the sampling period was $13 \pm 1 \mu \mathrm{g} / \mathrm{m}^{3}$, recorded during June $27^{\text {th }}$ and July $2^{\text {nd }}$, 2009 at the region of Layang Layang Island, located in the middle of the South China Sea. Whereas the highest TSP concentration $\left(74 \pm 4 \mu \mathrm{g} / \mathrm{m}^{3}\right)$ was recorded during July $30^{\text {th }}, 2009$ around Lahad Datu coastal waters in the Sulu Sea.

According to MMD, in the month of June 2009 experienced a weak to moderate southwest monsoon period which had brought warm and dry weather in the region [27]. Generally dry weather conditions except for occasional shower activities affected the southern ASEAN region of Brunei Darussalam, Indonesia, Malaysia and Singapore during most of June 2009 [28]. The rainfall received for most of the southern ASEAN region was also below normal with less than $50 \%$ of the normal rainfall recorded in southern Thailand, parts of Borneo and Sumatra, particularly in the fireprone province of Riau, central and southern Kalimantan [27, 28]. This dry weather conditions led to elevated hotspot activities in Sumatra in June 2009 [28].

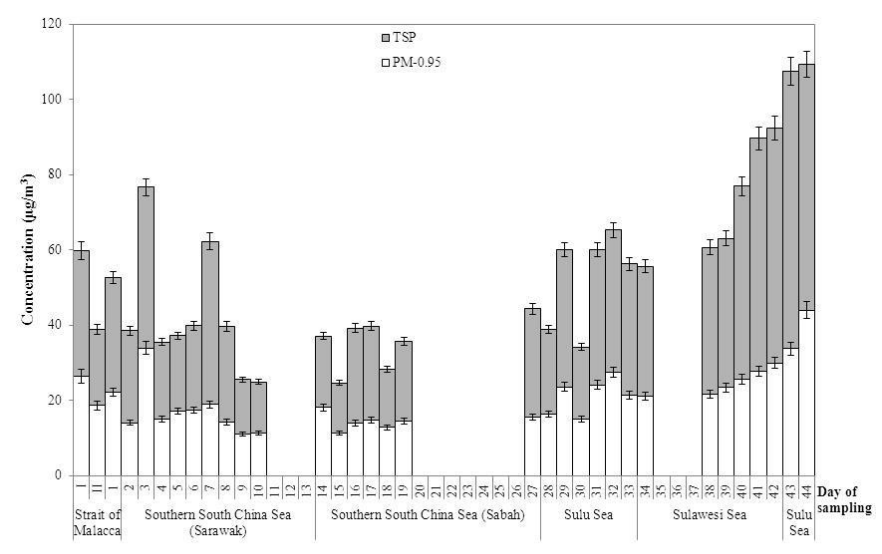

Figure 2: Total suspended particles (TSP) and particulate matter less than $0.95 \mu \mathrm{m}\left(\mathrm{PM}_{0.95}\right)$ concentrations $\left(\mu \mathrm{g} / \mathrm{m}^{3}\right)$ in maritime air collected during EPSP'09 Scientific Expedition

During the earlier part of the month, more hotspot counts due to forest fires were recorded for Sumatra Island than anywhere else, i.e. in Borneo and Peninsular Malaysia [28]. The prevailing southwest winds over the Riau area also brought smoke haze towards the western states of Peninsular Malaysia, particularly in Perak and Selangor. The air quality in Selangor was in the unhealthy range on 12 June 2009 and in Port Klang, the Air Pollution Index reached a high of 136 [29]. Utusan Malaysia in its report was saying this was due to peat bog fires occurred Klang, Shah alam and Kuala Langat [30]. At this period, samples were collected from Port Klang to Pulau Perak, Kedah via the Strait of Malacca channel. The highest TSP concentration in maritime air on the other hand was collected during Day I with $33 \pm 2 \mu \mathrm{g} / \mathrm{m}^{3}$ (Figure 2).

The second part of the sampling was taken from Port Kang to Labuan. (Figure 1 and 2). The highest TSP concentration in maritime air was recorded during the third day (20 till 21 June 2009) of EPSP'09 located in Southwest part of Sarawak waters with $43 \pm 2 \mu \mathrm{g} / \mathrm{m}^{3}$ (Figure 2). At this period, scattered hotspots were occasionally detected in Borneo Island particularly in Sarawak and West Kalimantan and also persistently detected with smoke plumes in northern and central Sumatra [28]. The TSP concentrations collected in southern South China Sea maritime air were markedly increased from $20 \pm 1 \mu \mathrm{g} / \mathrm{m}^{3}$ during 22 June 2009 to $43 \pm$ $2 \mu \mathrm{g} / \mathrm{m}^{3}$ during 24 June 2009 (Figure 2). Meanwhile, at the presence of rainfall activities had reduces the TSP concentrations in southern South China Sea maritime air, where it decreases from 24 June 2009 till the end of the second part of the sampling at Labuan on 27 June 2009 (Figure 2). The same argument was reported by MMD where the smoke haze in the southern ASEAN region was gradually improved with the return of rainfall activities giving wetter conditions throughout this region [27].

The third part of EPSP'09 expedition was started from Labuan during 1 July 2009 to Terumbu Layang-layang to Kota Kinabalu Naval Port during 6 July 2009. the TSP concentrations in Southern South China Sea (Terumbu Layang layang region) in this study were considerably lower than other sampling periods (Figure 2), which was averaged at $20 \pm 2$ $\mu \mathrm{g} / \mathrm{m}^{3}$ and ranged between $13 \pm 1 \mu \mathrm{g} / \mathrm{m}^{3}$ on Day 15 (2 July 2009) to $25 \pm$ $1 \mu \mathrm{g} / \mathrm{m}^{3}$ on Day 16 (3 July 2009). According to the Air Pollutant Index (API) data by Department of Environment, most of the areas (almost 64 - 80\%) in Malaysia were recorded good API which was below 50 [29]. However, slightly higher TSP concentration during day 16 was largely related to the emergence of hotspot activities with over 270 hotspot counts [28]. Smoke plumes detected in central and southern Sumatra during the prevailing dry weather which was suspected to be transported across the Straits of Malacca and consequently affected the Peninsular Malaysia [28].

The fourth part of EPSP'09 expedition was conducted from Kota Kinabalu Naval Port on 14 July 2009 until Tawau on 21 July 2009. The journey of EPSP'09 during this period was mainly covering Sulu Sea and the TSP concentration was averaged $31 \pm 4 \mu \mathrm{g} / \mathrm{m}^{3}$, which ranged between $19 \pm 1$ $\mu \mathrm{g} / \mathrm{m}^{3}$ on Day 30 (17 July 2009) to $38 \pm 2 \mu \mathrm{g} / \mathrm{m}^{3}$ on Day 32 (19 July 2009) (Figure 2). According to the National Environmental Agency of Singapore (NEA), persistent hotspot activities and smoke plumes detected in central and northern Sumatra, as well as West Kalimantan and Sarawak during 
second half of July where a possible transboundary smoke haze might have affected parts of Malaysia on several occasions during the month [28]. Meanwhile, wet weather conditions in the later part of the month helped to subdue the hotspot activities in Sumatra and Borneo [27].

The EPSP'09 was concluded with the fifth part of the expedition, returning from Tawau to Kota Kinabalu which was begun from Day 38 on 25 July 2009 until Day 44 on 1 August 2009 and covering much of the Sulawesi Sea area during Day 38 to Day 42 and little of Sulu Sea area during Day 43 to Day 44. However, the return of drier weather at the end of July 2009 with emergences of active hotspot activities in Sumatra and Borneo had resulted hazy weather and poor air quality in Sulu and Sulawesi Seas area [28]. Rainfall distribution was dropped from $40 \%$ to $60 \%$ below normal values [27]. The air quality during this period was also worsened by excessive vehicle and industrial emissions from Sabah and Sarawak big cities [31]. As consequence, the TSP concentrations during this period were increased from $39 \pm 2 \mu \mathrm{g} / \mathrm{m}^{3}$ in Day 38 (25 July 2009) to $74 \pm 4 \mu \mathrm{g} / \mathrm{m}^{3}$ in Day 43 (30 July 2009), averaging $56 \pm 8 \mu \mathrm{g} / \mathrm{m}^{3}$ (Figure 2).

\section{2. ${ }^{210} \mathrm{~Pb}$ and ${ }^{210} \mathrm{Po}$ activity concentrations and ${ }^{210} \mathrm{Po} /{ }^{210} \mathrm{~Pb}$ activity ratios}

Based on Table 1, the ${ }^{210} \mathrm{~Pb}$ activity concentrations in this study was varied between $180 \pm 52 \mu \mathrm{Bq} / \mathrm{m}^{3}$ to $2315 \pm 662 \mu \mathrm{Bq} / \mathrm{m}^{3}$ with mean $908 \pm 272$ $\mu \mathrm{Bq} / \mathrm{m}^{3}$. Meanwhile for ${ }^{210} \mathrm{Po}$, the activity was varied between $80 \pm 8$ $\mu \mathrm{Bq} / \mathrm{m}^{3}$ to $2039 \pm 214 \mu \mathrm{Bq} / \mathrm{m}^{3}$ with mean $664 \pm 68 \mu \mathrm{Bq} / \mathrm{m}^{3}$. The range of ${ }^{210} \mathrm{~Pb}$ and ${ }^{210} \mathrm{Po}$ activity concentrations at natural ground levels according to Porstendörfer et al. are between $200-1500 \mu \mathrm{Bq} / \mathrm{m}^{3}$ and $30-300 \mu \mathrm{Bq} / \mathrm{m}^{3}$, respectively [32]. Thus, it is worth to note that the ${ }^{210} \mathrm{Po}$ activity concentration from this study was highly enriched compared to the natural level where it is primarily produced by radioactive decay of the progenitor ${ }^{222} \mathrm{Rn}$, which emanates from continental surfaces [13]

Table 1: Comparison between total suspended particles (TSP), natural radionuclide $\left({ }^{210} \mathrm{~Pb}\right.$ and $\left.{ }^{210} \mathrm{Po}\right)$ activity concentrations and ${ }^{210} \mathrm{Po} /{ }^{210} \mathrm{~Pb}$ activity ratio in the Malaysian maritime air collected during EPSP'09 Scientific Expedition.

\begin{tabular}{|c|c|c|c|c|c|}
\hline Sampling date & $\begin{array}{c}\text { TSP } \\
\left(\mu \mathrm{g} / \mathrm{m}^{3}\right)\end{array}$ & $\begin{array}{c}{ }^{210} \mathrm{~Pb} \\
\mu \mathrm{Bq} / \mathrm{m}^{3}\end{array}$ & $\begin{array}{c}{ }^{210} \mathrm{Po} \\
\mu \mathrm{Bq} / \mathrm{m}^{3}\end{array}$ & $\begin{array}{l}{ }^{210} \mathrm{Po} /{ }^{210} \mathrm{~Pb} \\
\text { activity } \\
\text { ratio }\end{array}$ & $\begin{array}{l}\text { Atmospheric } \\
\text { observation }\end{array}$ \\
\hline 12-Jun-09 & $33 \pm 3$ & $249 \pm 73$ & $558 \pm 56$ & $2.24 \pm 0.69$ & Hazy \\
\hline 13-Jun-09 & $20 \pm 2$ & $247 \pm 71$ & $363 \pm 37$ & $1.47 \pm 0.45$ & Hazy \\
\hline 18-Jun-09 & $30 \pm 2$ & $180 \pm 52$ & $418 \pm 42$ & $2.33 \pm 0.72$ & Clear \\
\hline 19-Jun-09 & $25 \pm 1$ & $232 \pm 67$ & $736 \pm 74$ & $3.17 \pm 0.97$ & Hazy \\
\hline 20-Jun-09 & $43 \pm 2$ & $331 \pm 98$ & $1099 \pm 111$ & $3.32 \pm 1.04$ & Hazy \\
\hline 21-Jun-09 & $21 \pm 1$ & $295 \pm 86$ & $863 \pm 87$ & $2.93 \pm 0.90$ & Hazy \\
\hline 22-Jun-09 & $20 \pm 1$ & $304 \pm 90$ & $954 \pm 96$ & $3.13 \pm 0.98$ & Hazy \\
\hline 23-Jun-09 & $22 \pm 1$ & $792 \pm 227$ & $1056 \pm 106$ & $1.33 \pm 0.40$ & Hazy and rain \\
\hline 24-Jun-09 & $43 \pm 2$ & & $512 \pm 52$ & & Clear and rain \\
\hline 25-Jun-09 & $25 \pm 1$ & & $355 \pm 36$ & & Clear and rain \\
\hline 26-Jun-09 & $14 \pm 1$ & & $377 \pm 38$ & & Clear \\
\hline 27-Jun-09 & $13 \pm 1$ & & $420 \pm 42$ & & Clear and rain \\
\hline 1-Jul-09 & $19 \pm 1$ & & $250 \pm 26$ & & Clear \\
\hline 2-Jul-09 & $13 \pm 1$ & & $301 \pm 30$ & & Clear and rain \\
\hline 3-Jul-09 & $25 \pm 1$ & & $351 \pm 35$ & & Clear and rain \\
\hline 4-Jul-09 & $25 \pm 1$ & & $203 \pm 20$ & & Clear and rain \\
\hline 5-Jul-09 & $16 \pm 1$ & $1028 \pm 294$ & $297 \pm 30$ & $0.29 \pm 0.09$ & Clear \\
\hline 6-Jul-09 & $21 \pm 1$ & & $422 \pm 42$ & & Clear and rain \\
\hline 14-Jul-09 & $29 \pm 1$ & & $628 \pm 63$ & & Clear \\
\hline 15-Jul-09 & $23 \pm 1$ & & $80 \pm 8$ & & Clear \\
\hline 16-Jul-09 & $36 \pm 2$ & & $773 \pm 78$ & & Hazy and dry \\
\hline 17-Jul-09 & $19 \pm 1$ & & $592 \pm 60$ & & Hazy \\
\hline 18-Jul-09 & $36 \pm 2$ & & $501 \pm 51$ & & Clear \\
\hline
\end{tabular}

\begin{tabular}{lcccll} 
19-Jul-09 & $38 \pm 2$ & & $584 \pm 59$ & & Clear and rain \\
20-Jul-09 & $35 \pm 2$ & & $427 \pm 43$ & & Clear and rain \\
21-Jul-09 & $35 \pm 2$ & & $372 \pm 37$ & & Clear \\
25-Jul-09 & $39 \pm 2$ & & $495 \pm 50$ & & Clear and rain \\
26-Jul-09 & $40 \pm 2$ & $1649 \pm 464$ & $397 \pm 40$ & $0.24 \pm 0.07$ & Clear \\
27-Jul-09 & $51 \pm 3$ & $1222 \pm 349$ & $636 \pm 64$ & $0.52 \pm 0.16$ & Hazy and rain \\
28-Jul-09 & $62 \pm 3$ & & $1392 \pm 140$ & & Hazy \\
29-Jul-09 & $62 \pm 3$ & $2315 \pm 662$ & $1590 \pm 160$ & $0.69 \pm 0.21$ & Hazy \\
30-Jul-09 & $74 \pm 4$ & $1841 \pm 527$ & $1857 \pm 187$ & $1.01 \pm 0.31$ & Hazy \\
31-Jul-09 & $65 \pm 3$ & $2031 \pm 593$ & $2039 \pm 214$ & $1.00 \pm 0.31$ & Hazy \\
\hline
\end{tabular}

The observed ${ }^{210} \mathrm{~Pb}$ and ${ }^{210} \mathrm{Po}$ activity concentrations present a similar variation in the air with the highest concentrations during warm period of southwest monsoon (Figure 2). This is also coincided to the small amount of precipitation (rainfall) and stagnant mixing conditions in the troposphere due to stable atmosphere reducing the convection activities which lead to the drier and hazy condition during this period as discussed in TSP variations. A positive proportion of ${ }^{210} \mathrm{~Pb}$ and ${ }^{210} \mathrm{Po}$ activity concentrations and the TSP pattern in Fig. 3 could further support the argument. This analysis showed significant relationship of ${ }^{210} \mathrm{Po}$ and ${ }^{210} \mathrm{~Pb}$ variations to TSP concentrations pattern due to forest and peat bog burning and anthropogenic emissions from vehicles and industrial plants. During the haze episode, the TSP concentrations in maritime air increased by a factor of 10 compared to ambient value for TSP of $10 \mu \mathrm{g} / \mathrm{m}^{3}$ [1] Simultaneously there was an increase of the same order of magnitude in the concentrations of ${ }^{210} \mathrm{~Pb}$ and ${ }^{210} \mathrm{Po}$ during the haze episode (Figure 3).

Such discrepancies have been explained by Sabuti and Mohamed where the excess of ${ }^{210} \mathrm{~Pb}$ and ${ }^{210} \mathrm{Po}$ in this region is due to re-suspension of organic particulate matter from forest and peat bog burning and anthropogenic emissions from vehicles and industrial plants [33]. This contribution of re-suspension effects can be further explained from the particle size distribution of an aerosol, in which only coarse particles with sizes larger than $1 \mu \mathrm{m}$ would being re-suspended [34]. Data from Table 2 is proving this relationship between coarse particles (size more than 0.95 $\mu \mathrm{m})$ and ${ }^{210} \mathrm{~Pb}$ and ${ }^{210} \mathrm{Po}$ activities using Pearson correlation coefficient. There was a stronger positive correlation between coarse particulate $(\mathrm{PM}>0.95)$ with ${ }^{210} \mathrm{Po}(\mathrm{r}=0.728, \mathrm{~N}=33, \mathrm{p}<0.01)$ than ${ }^{210} \mathrm{~Pb}(\mathrm{r}=0.383, \mathrm{~N}$ $=33, \mathrm{p}<0.05$ ).

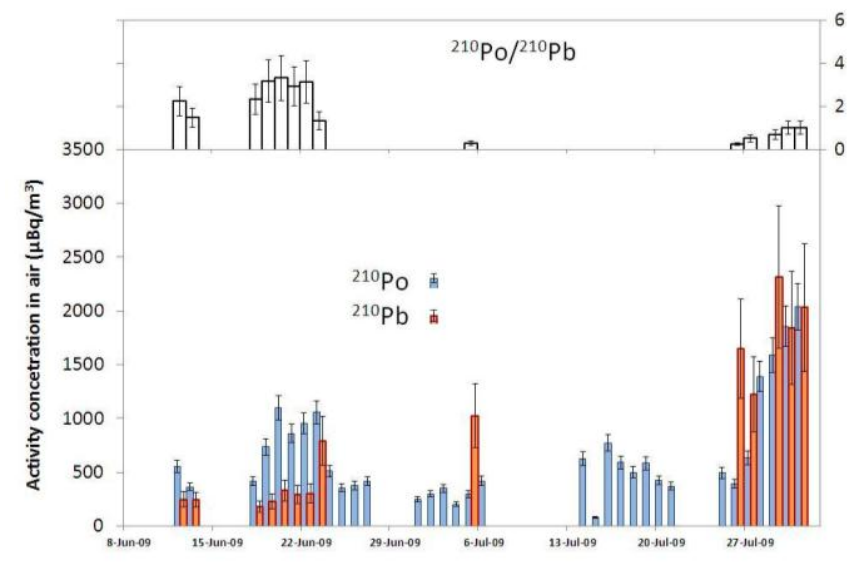

Figure 2: Natural radionuclide $\left({ }^{210} \mathrm{~Pb}\right.$ and $\left.{ }^{210} \mathrm{Po}\right)$ activity concentrations and ${ }^{210} \mathrm{Po} /{ }^{210} \mathrm{~Pb}$ activity ratio in the Malaysian maritime air collected during EPSP'09 Scientific Expedition

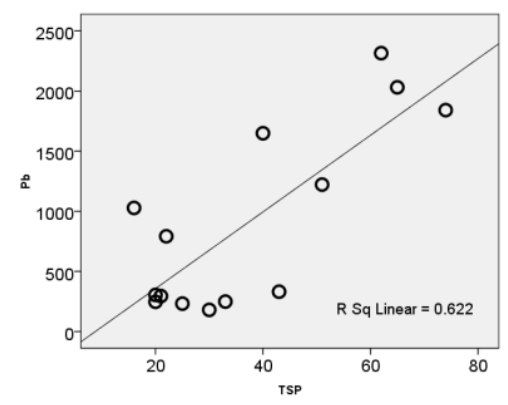




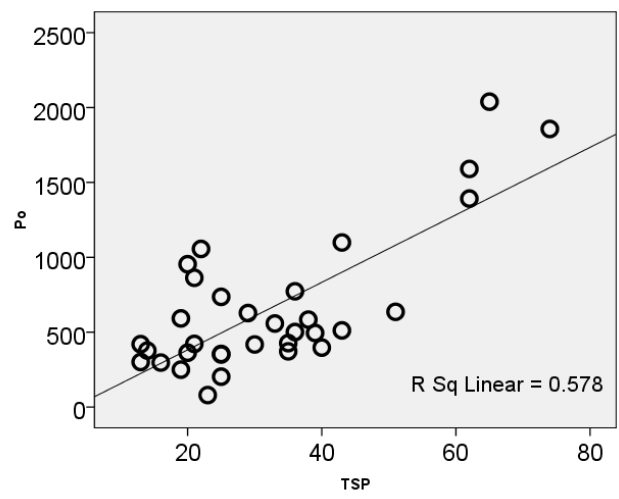

Figure 3: Linear correlation between natural radionuclide $\left({ }^{210} \mathrm{~Pb}\right.$ and ${ }^{210} \mathrm{Po}$ ) activity concentrations and the TSP concentrations in the Malaysian maritime air collected during EPSP'09 Scientific Expedition.

Table 2: Pearson correlation analysis to describe the linear relationship between coarse particles (particulate matter larger than $0.95 \mu \mathrm{m}$ ) concentrations with ${ }^{210} \mathrm{~Pb}$ and ${ }^{210} \mathrm{Po}$ activity concentrations

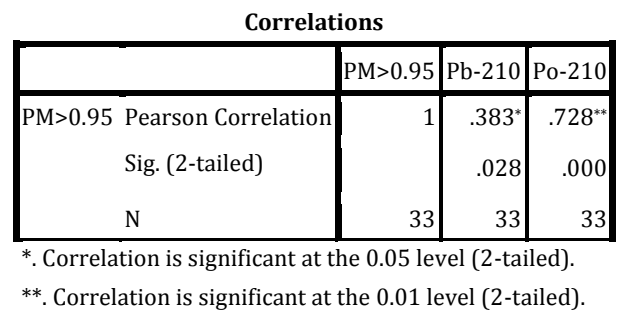

Meanwhile, the ${ }^{210} \mathrm{Po} /{ }^{210} \mathrm{~Pb}$ activity ratio at natural levels only at approximately 0.06 to 0.10 [35-38]. However, this is only true when the decay of radon gas is the only source of these two radionuclides and the mean residence time of dust suspended in the troposphere is about 15 days therefore there is little time for ${ }^{210} \mathrm{Po}$ to be formed in suspended dust. Since ${ }^{210} \mathrm{~Pb}$ and ${ }^{210} \mathrm{Po}$ has been known for their reactivity to particles, the availability of particulate matter in air column may be a major factor for the levels of these radionuclide activities [39]. Almost all samples have recorded ${ }^{210} \mathrm{Po} /{ }^{210} \mathrm{~Pb}$ activity ratios exceeding unity value, with the highest was $3.32 \pm 1.04$ (Table 1, Figure 2). It is notably higher than the value of maritime aerosol from the eastern Pacific, $0.07 \pm 0.04$ [38].

The ${ }^{210} \mathrm{Po} /{ }^{210} \mathrm{~Pb}$ activity ratios in atmosphere can be increased than the usual $4-5 \%$ to as high as $300 \%$ [24]. The high ${ }^{210} \mathrm{Po}$ activity concentration levels in atmosphere from this study have been suspected due to significant enrichment from additional source, presumably by injection of ${ }^{210} \mathrm{Po}$ excess to the region $[33,40]$. This also gives us understanding that during dry seasons, the possibility of getting high radionuclide aerosols due to the availability of dust particles which especially from forest fires in air column will be higher $[33,39]$. Significant contributions of biogenic particles from fossil fuel burning by-products has also been reported elsewhere $[18,20,39,41,42]$.

In addition, one of the main reason is due to polonium is more volatile than lead thus ${ }^{210} \mathrm{Po}$ content was in excess compared to ${ }^{210} \mathrm{~Pb}$ [42]. On the other hand, the continuous atmospheric photochemistry induced by solar radiation could also be less effective during hazy condition, causing less vertical mixing of the troposphere [43]. Thus, based on previous discussions, we might consider the longer atmospheric residence time of aerosols and enrichment of ${ }^{210} \mathrm{Po}$ from forest and peat bog burning and as well as vehicles and industrial plants emissions in which ${ }^{210} \mathrm{~Pb}$ and ${ }^{210} \mathrm{Po}$ are not in secular equilibrium and resulting higher ${ }^{210} \mathrm{Po} /{ }^{210} \mathrm{~Pb}$ activity ratios. These are possible factors increase the aerosol residence time and thus accumulation of ${ }^{210} \mathrm{~Pb}$ and ${ }^{210} \mathrm{Po}$ into the air.

\section{CONCLUSIONS}

The range and average of TSP concentrations were indicating high total suspended particles presence in the maritime air during the EPSP'09 Scientific Expedition, which therefore relating to regional forest and peat bog fires and smokes from vehicles and industries emissions creating haze situation. Southwest monsoon period (May - September) had brought warm and dry weather in the region led to elevated forest and peat bog fires and smokes from vehicles and industries emissions activities. A more stable atmosphere during southwest monsoon also reducing the convection activities which lead to the drier and hazy condition during this period and led to an increase the aerosol residence time and thus accumulation of ${ }^{210} \mathrm{~Pb}$ into the air. The longer atmospheric residence time of aerosols could affect the enrichment of ${ }^{210} \mathrm{~Pb}$ and ${ }^{210} \mathrm{Po}$ from different contribution of radionuclide sources in which ${ }^{210} \mathrm{~Pb}$ and ${ }^{210} \mathrm{Po}$ are not in secular equilibrium and resulting larger than unity of ${ }^{210} \mathrm{Po} /{ }^{210} \mathrm{~Pb}$ activity ratios.

\section{ACKNOWLEDGEMENT}

Authors would like to thank the organisers of EPSP'09 Scientific Expedition, National Oceanography Directorate (NOD) ofMinistry of Science, Technology and Innovation (MOSTI), Malaysia, and Royal Malaysian Navy. The crew of KD Perantau and all EPSP'09 participants from government's agencies and universities, Universiti Kebangsaan Malaysia, as well as Land-Atmospheric-Ocean Interaction (LAOI) Research Group in UKM.

\section{REFERENCES}

[1] Alias, M., Zaini, H., Lee, S.K. 2007. $\mathrm{PM}_{10}$ and Total Suspended Particulates (TSP) measurements in various power stations. The Malaysian Journal of Analytical Sciences, 11, 255-261.

[2] Levy, J., Hammitt, K.J., Spengler, D.J. 2000. Estimating the mortality impact of particulate matter: What can be learned from Between-Study Variability. Environmental Health Perspectives, 108, 109-117.

[3] Youngsin, C., Lim, J.Y. 2004. The recent characteristics of Asian Dust and haze events in Seoul, Korea. Meteorology and Atmospheric Physics, $87,143-152$.

[4] WDNR (Wisconsin Department of Natural Resources). 2006. Total suspended particulates, Wisconsin Dept. of Natural Resources, retrieved at
16
March
2006

http://www.dnr.state.wi.us/org/aw/air/health/tspart.htm

[5] Larson, T.V., Koenig, J.Q. 1994. Wood smoke emissions and noncancer respiratory effects. Annual Review of Public Health, 15, 133156.

[6] Ward, D.E. 1990. Factors influencing the emissions of gases and particulate matter from biomass burning. In: Goldammer, J.G. (ed). Fire in the tropical biota: ecosystem processes and global challenges. p. 418-436. Heidelberg: Springer-Verlag Berlin,

[7] Manö, S., Andrae, M.O. 1994. Emissions of methyl bromide from biomass burning. Science, 261, 1255-1257.

[8] Mukherjee, D. 1997. Health impact of polychlorinated dibenzino-pdioxins: a critical review. Journal of the Air and Waste Management Association, 48, 157-165.

[9] Junge, C.E. 1963. Air Chemistry and Radioactivity. Academic Press: New York.

[10] Amiro, B.D., Sheppard, S.C., Johnston, F.L., Evenden, W.G., Harris, D.R 1996. Burning radionuclide question: What happens to iodine, caesium and chlorine in biomass fires? The Science of the Total Environment, 187, 93-103.

[11] Baskaran, M., Shaw, G.E. 2001. Residence time of arctic haze aerosols using the concentrations and activity ratios of ${ }^{210} \mathrm{Po},{ }^{210} \mathrm{~Pb}$ and ${ }^{7} \mathrm{Be}$ Aerosol Science, 32, 443-452.

[12] Caillet, S., Arpagaus, P., Monna, F., Dominik, J. 2001. Factors controlling ${ }^{210} \mathrm{~Pb}$ and ${ }^{7} \mathrm{Be}$ atmospheric deposition as revealed by sampling individual events in the region of Geneva, Switzerland. Journal of Environmental Radioactivity, 53, 241-256.

[13] Carvalho, F.P. 1995b. Origins and concentrations of ${ }^{222} \mathrm{Rn},{ }^{210} \mathrm{~Pb},{ }^{210} \mathrm{Bi}$ and ${ }^{210} \mathrm{Po}$ in the surface air at Lisbon, Portugal, at the Atlantic edge of the European continental landmass. Atmospheric Environment, 29, 18091819.

[14] Hirose, K., Honda, T., Yagishita, S., Igarashi, Y., Aoyama, M. 2004 Deposition behaviours of ${ }^{210} \mathrm{~Pb},{ }^{7} \mathrm{Be}$ and thorium isotopes observed in Tsukuba and Nagasaki, Japan. Atmospheric Environment, 38, 6601-6608.

[15] Marley, N.A., Gaffney, J.S., Cunningham, M.M., Orlandini, K.A., Paode, R., Dryton, P.J. 2000 . Measurement of ${ }^{210} \mathrm{~Pb},{ }^{210} \mathrm{Po}$ and ${ }^{210} \mathrm{Bi}$ in size 
fractionated atmospheric aerosols: an estimate of five aerosol residence time. Aerosol Science and Technology, 32, 569-583.

[16] Gaffney, J.S., Marley, N.A., Cunningham, M.M. 2004. Naturally radionuclides in five aerosols in the Pittsburgh area. Atmospheric Environment, 38 (20), 3191-3200.

[17] Papastefanou, C. 2006. Residence time of tropospheric aerosols in association with radioactive nuclides. Applied Radiation and Isotopes, 64, 93-100.

[18] UNSCEAR. 1993. Exposure from natural sources of radiation. General assembly with annexes. New York: United Nations Scientific Committee on the Effects of Atomic Radiation.

[19] Bem, H., Wieczorkowski, P., Budzanowski, M. 2002. Evaluation of technologically enhanced natural radiation near the coal-fired power plants in the Lodz region of Poland. Journal of Environmental Radioactivity, 61, 191-201.

[20] Flues, M., Camargo, I.M.C., Figueiredo-Filho, P.M., Silva, P.S.C., Mazzilli, B.P. 2007. Evaluation of radionuclides concentration in Brazilian coals. Fuel, 86, 807-812.

[21] Germain, P., Leclerc, G., Simon, S. 1995. Transfer of polonium-210 into Mytilusedulis (L.) and FucusVesiculosus (L.) from the Baie de Seine (Channel coast of France). The Science of the Total Environment, 164, 109123.

[22] Carvalho, F.P. $1995 \mathrm{a} .{ }^{210} \mathrm{~Pb}$ and ${ }^{210} \mathrm{Po}$ in sediment and suspended matter in the Tagus estuary. Local enhancement of natural levels by wastes from phosphate ore processing industry. The Science of the Total Environment, 159, 201-214.

[23] Malilay, J. 1998. A review of factors affecting the human health impacts of air pollutants from forest fires. In Goh, K.-T., Schwela, D. and Goldammer, J.G. (eds.) Health Guidelines for Vegetation Fire Events Background. p. 258-283, Geneva: World Health Organization.

[24] Paatero, J., Vesterbacka, K., Makkonen, U., Kyllönen, K., Hallen, H., Hatakka, J., Anttila, P. 2009. Resuspension of radionuclides into the atmosphere due to forest fires. Journal of Radioanalytical Nuclear Chemistry, 282, 473-476.

[25] Daish, S.R., Dale, A.A., Dale, C.J., May, R., Rowe, J.E. 2005. The temporal variations of ${ }^{7} \mathrm{Be},{ }^{210} \mathrm{~Pb}$ and ${ }^{210} \mathrm{Po}$ in air in England. Journal of Environmental Radioactivity, 84, 457-467.

[26] Murray, M.K., Chung-Kyu, K., Paul, M. 2007. Determination of ${ }^{210} \mathrm{Po}$ in environmental samples. A review of analytical methodology. Applied Radiation and Isotopes, 65 (3), 267-279.

[27] MMD (Malaysian Meteorological Department). 2010. Monthly Weather Bulletin, retrieved at 17 April 2010 at http://www.met.gov.my/index.php.

[28] NEA (National Environment Agency, Singapore). 2010. Monthly Weather and Haze Outlook Archives, retrieved at 25April 2010 at http://www.weather.gov.sg/wip/web/ASMC/ home.

[29] DOE (Department of Environment, Malaysia). 2010. Air Pollutant Index Management System (APIMS), Malaysian Department of
Environment, retrieved at 15 April 2010 at http://www.doe.gov.my/apims/

[30] Utusan Malaysia. 2005. 2 tempat darudat - IPU di Kuala Selangor dan Pelabuhan Klang melepasi 500. Arkib 12 Ogos 2005 [15 September 2009]. http://www.utusan.com.my/

[31] BeritaHarian. 2009. Sabah \& Sarawak: Asap kenderaan berlebihan punca kualiti udara merosot, retrieved 7 August 2009 at http://www.bharian.com.my/bharian/arkib html.

[32] Porstendörfer J., Reineking A., Butterweck G., El-Hussein A. 1990. Radioactive aerosol in the lower atmosphere, Masuda S., Takashi K., Aerosol: Science, Industry, Health and Environment, 1217 - 1221, Pergamon Press, Oxford

[33] Sabuti, A.A., Mohamed, C.A.R. 2016. Impact of northern and southern air mass transport on the temporal distribution of atmospheric ${ }^{210} \mathrm{Po}$ and ${ }^{210} \mathrm{~Pb}$ in the east coast of Johor, Malaysia. Environmental Science and Pollution Research, 23 (18), 18451-18465.

[34] Wallner, G., Berner, A., Irlweck, K. 2002. Aerosols: unexpected disequilibrium phenomena between airborne radio activities of lead-210 and its progenies bismuth-210 and polonium-210. Naturwissenschaften $89,569-574$

[35] Burton, W.M., Stewart, N.G. 1960. Use of long-lived natural radioactivity as an atmospheric tracer. Nature 186, 584-589.

[36] Peirson, D. H., Cambray, R. S., Spicer, G. S. 1966. Lead-210 and polonium-210 in the atmosphere. Tellus, 18, 427-433.

[37] Poet, S.E., Moore, H.E., Martell, E.A. 1972. Lead-210, bismuth-210 and polonium-210 in the atmosphere: Accurate ratio measurement and application to aerosol residence time determination. Journal of Geophysical Research, 77, 6515-6527.

[38] Moore, H.E., Poet, S.E., Martell, E.A. 1977. Vertical profiles of ${ }^{222} \mathrm{Rn}$ and its long-lived daughters over the eastern Pacific. Environmental Science and Technology, 11, 1207-1210.

[39] Sabuti, A.A., Mohamed, C.A.R. 2011. Natural radioisotopes of Pb, Bi and Po in the atmosphere of coal burning area. Environment Asia, 4 (2), 49-62.

[40] Sabuti, A.A., Mohamed, C.A.R. 2015. High 210Po activity concentration in the surface water of Malaysian seas driven by the dry season of the southwest monsoon (June-August 2009). Estuaries and coasts, 38 (2), 482 $-493$.

[41] Beck, H.L., Miller, K.M. 1980. Some radiological aspects of coal combustion. IEEE Transactions on Nuclear Science NS-27, (1), 689-694.

[42] Karangelos, D.J., Petropoulos, N.P., Anagnostakis, M.J., Hinis, E.P., Simopoulos, S.E. 2004. Radiological characteristics and investigation of the radioactive equilibrium in the ashes produced in lignite-fired power plants. Journal of Environmental Radioactivity, 77, 233-246.

Paatero, J., Hattaka, J. 2000. Source areas of airborne ${ }^{7} \mathrm{Be}$ and ${ }^{210} \mathrm{~Pb}$ measured in Northern Finland. Health Physics, 79, 691-696. 